\title{
Autologous fascia lata transplantation for heart valve replacement
}

\author{
A two-year experience at the National Heart Hospital, London \\ H. DALICHAU ${ }^{1}$, L. GONZALEZ-LAVIN ${ }^{2}$, and D. N : ROS \\ Department of Surgery, Institute of Cardiology, and National Heart Hospital, London
}

\begin{abstract}
Between April 1969 and December 1970, 201 patients underwent 262 valve replacements with frame-mounted autologous fascia lata valves in the aortic, mitral, and/or tricuspid positions at the National Heart Hospital. A single fascia lata valve was inserted in 146 patients and multivalve replacement was performed in 55 instances. Hospital and late mortality are comparable with that following other procedures of heart valve replacement. One hundred and fifty-four patients with 193 fascia lata valves were available for follow-up. A retrospective analysis of this method of valve replacement has been undertaken to assess the suitability of fascia lata as a heart valve substitute as well as the clinical results achieved by this method of valve replacement.
\end{abstract}

In the pursuit of an ideal valve substitute (Ross, 1962; Ross, 1967; Gonzalez-Lavin and Ross, 1970; Gonzalez-Lavin and Ross, 1971b ; Gonzalez-Lavin, Geens, Somerville, and Ross, 1970b) and stimulated by reports of the clinical use of free fascia lata valves in the aortic position (Senning, 1967; Senning, 1969; Edwards, 1969; Edwards, Karp, Robillard, and Kerr, 1969), Ionescu and Ross (1969) developed a method of fabricating a three-leaflet fascia lata valve mounted on a Dacron-covered metal frame. The valve design permits its use in the aortic, mitral or tricuspid position.

The major advantage of this valve was thought to be that it is made of an autologous tissue that should remain alive after implantation. This tissue is constantly available and the valves can be constructed in different sizes. Technical details of the fabrication and insertion of these valves have been described (Ionescu and Ross, 1969; Ionescu et al., 1970a, 1970c).

Now that more than two years have elapsed since the introduction of this method, a retrospective analysis can be undertaken in regard to the valve design and the suitability of fascia lata, as well as to the clinical results achieved by this procedure of heart valve replacement.

1Present address : Medizinische Hochule, Chirurgische Klinik, Podbielski Str. 380, Hanover, West Germany

2Address all communications and reprint requests to : L. GonzalezLavin, M.D., Institute of Cardiology, 35 Wimpole Street, London, W1M 8EX
Techniques of fabricating an unsupported aortic valve (Wright, Ross, and Yates, 1971; Dalichau, Mahjoub, and Ross, 1971; Yates, 1971) and an unsupported mitral valve (Brownlee and Yates, 1971; Dalichau, 1971) were devised and tested experimentally. They have been used in a limited number of patients near the end of the series and are not comparable with the large group of patients with frame-mounted fascial valves. This report will therefore be confined to patients with supported fascia lata valves.

\section{CLINICAL MATERIAL}

Two hundred and one patients underwent 262 valve replacements with a frame-mounted fascial valve in the aortic, mitral, and/or tricuspid position between April 1969 and December 1970 at the National Heart Hospital. Seventy-nine patients were females and 122 were males; the majority were in the fifth and sixth decades (Fig. 1). One hundred and eighteen patients $(58 \%)$ had had rheumatic fever $(76 \%$ of those patients having mitral valve involvement gave a positive history of rheumatic fever). Nineteen patients $(9.4 \%) 0$ had a history of bacterial endocarditis. Fifty-nine of $\bar{\varnothing}$ the replaced valves had undergone previous surgical on attention $(22.9 \%)$; in 29 of these valves a conservative procedure had been done and in the other 30 replacement of the valve had been performed.

A single fascia lata valve was inserted in 146 patients; double or triple valve replacements were performed in 55 instances $(21 \%)$. Concomitant surgery was necessary in 38 patients (18\%) (Table I). 


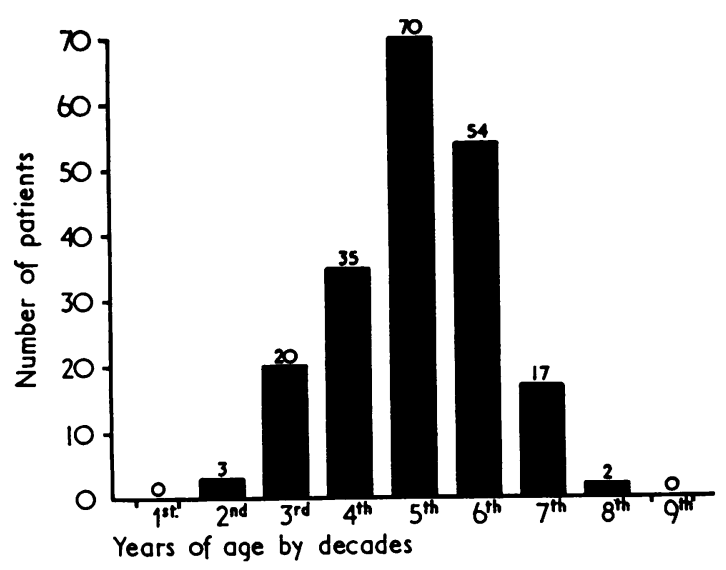

FIG. 1. Years of age by decades of 201 patients undergoing fascia lata valve replacement. Figures at top of columns refer to numbers of patients.

T A B LE I

OPERATIVE PROCEDURES CONCOMITANT WITH FASCIA LATA VALVE REPLACEMENT

\begin{tabular}{|c|c|c|}
\hline Primary Procedure & Concomitant Procedure & \\
\hline $\begin{array}{l}\text { Replacement of: } \\
\text { Aortic valve (85) }\end{array}$ & $\begin{array}{l}\text { Mitral valvotomy } \\
\text { Closure ventricular septal defect } \\
\text { Repair 'Jet Lesion' to mitral valve } \\
\text { (1 with subaortic myotomy) } \\
\text { Obliteration subaortic aneurysm } \\
\text { Reconstruction aortic root } \\
\text { Subvalvar myotomy } \\
\text { Replacement of ascending aorta } \\
\text { Reimplantation coronary artery }\end{array}$ & $\begin{array}{r}4 \\
3 \\
2 \\
2 \\
2 \\
2 \\
1 \\
1 \\
17\end{array}$ \\
\hline Mitral valve (57) & $\begin{array}{l}\text { Tricuspid annuloplasty } \\
\text { Homograft replacement aortic valve } \\
\text { Repair aortic valve with fascia lata } \\
\text { Prosthetic replacement aortic valve } \\
\text { Subaortic myotomy } \\
\text { Closure aorto-right atrial } \\
\text { communication } \\
\text { Correction atrial ventricular canal }\end{array}$ & $\begin{array}{r}6 \\
4 \\
2 \\
1 \\
1 \\
1 \\
1 \\
16\end{array}$ \\
\hline $\begin{array}{l}\text { Tricuspid valve (4) } \\
\text { Aortic and mitral } \\
\text { valves (43) } \\
\text { Mitral and tricuspid } \\
\text { valves (6) } \\
\text { Triple valve (6) }\end{array}$ & $\begin{array}{l}\text { Closure atrial septal defect } \\
\text { Subaortic myotomy } \\
\text { Closure atrial septal defect } \\
\text { Aortic valvotomy }\end{array}$ & $\begin{array}{l}1 \\
1 \\
1 \\
2 \\
0\end{array}$ \\
\hline Total & & $\begin{array}{c}38 \\
(18 \%\end{array}$ \\
\hline
\end{tabular}

\section{RESULTS}

Among the entire group of 201 patients, 32 died within $\mathbf{3 0}$ days of surgery for a hospital mortality of $15.9 \%$ (Table II). The causes of death are tabulated in Table III. Of the 169 patients leaving hospital, $19(9.4 \%)$ subsequently died. Deaths were due to bacterial endocarditis in six, myocardial failure in six, re-operation for valve failure in two, and various other causes (Table III).

T A B L E I I

MORTALITY IN 201 PATIENTS AFTER HEART VALVE REPLACEMENT WITH SUPPORTED FASCIA LATA VALVES

\begin{tabular}{l|c|c|c}
\hline \multirow{2}{*}{ Valve Replacement } & $\begin{array}{c}\text { No. of } \\
\text { Patients }\end{array}$ & \multicolumn{2}{|c}{ Mortality } \\
\cline { 3 - 4 } & & Hospital & Late \\
\hline Single: & 85 & $5(5.8 \%)$ & $6(7.1 \%)$ \\
$\quad \begin{array}{c}\text { Aortic } \\
\text { Mitral } \\
\text { Tricuspid }\end{array}$ & 57 & $9(15.6 \%)$ & $8(14.2 \%)$ \\
Double: & 4 & $1(25.0 \%)$ & 0 \\
$\begin{array}{l}\text { Aortic and mitral } \\
\text { Mitral and tricuspid }\end{array}$ & 43 & $9(20.9 \%)$ & $3(7.0 \%)$ \\
Triple: & 6 & $4(66.6 \%)$ & $1(16.7 \%)$ \\
\hline Total & 6 & $4(66.6 \%)$ & $1(16.7 \%)$ \\
\hline
\end{tabular}

T A B L E III

CAUSES OF EARLY AND LATE DEATHS AFTER SUPPORTED FASCIA LATA VALVE REPLACEMENT(S)

\begin{tabular}{|c|c|c|c|}
\hline $\begin{array}{l}\text { Valves } \\
\text { Replaced }\end{array}$ & Hospital Deaths & & Late Deaths \\
\hline Aortic & $\begin{array}{l}\text { Ventricular fibrillation } \\
\text { LVOFT-thrombosis } \\
\text { Cerebral damage } \\
\text { Renal failure } \\
\text { Hepatic coma }\end{array}$ & $\begin{array}{l}1 \\
1 \\
1 \\
1 \\
1\end{array}$ & $\begin{array}{l}\text { Heart failure } \\
\text { Bacterial endocarditis }\end{array}$ \\
\hline Mitral & $\begin{array}{l}\text { Low cardiac output } \\
\text { Lt. heart failure } \\
\text { Bleeding } \\
\text { Mesenteric embolism } \\
\text { Cerebral embolism } \\
\text { Renal failure }\end{array}$ & $\begin{array}{l}4 \\
1 \\
1 \\
1 \\
1 \\
1\end{array}$ & $\begin{array}{l}\text { Bacterial endocarditis } \\
\text { Lt. heart failure } \\
\text { Pneumonia } \\
\text { Pulmonary infarction } \\
\text { Viral hepatitis }\end{array}$ \\
\hline Tricuspid & Pulmonary embolism & 1 & \\
\hline $\begin{array}{l}\text { Aortic and } \\
\text { Mitral }\end{array}$ & $\begin{array}{l}\text { Low cardiac output } \\
\text { Lt. heart failure } \\
\text { Bleeding } \\
\text { Cerebral damage } \\
\text { Renal failure }\end{array}$ & $\begin{array}{l}4 \\
1 \\
2 \\
1 \\
1\end{array}$ & $\begin{array}{l}\text { Bacterial endocarditis } \\
\text { MR - without reoperation } \\
\text { — with reoperation }\end{array}$ \\
\hline $\begin{array}{l}\text { Mitral and } \\
\text { tricuspid }\end{array}$ & $\begin{array}{l}\text { Low cardiac output } \\
\text { Sudden death } \\
\text { (unexplained) }\end{array}$ & $\begin{array}{l}3 \\
1\end{array}$ & TR-with reoperation \\
\hline Triple & $\begin{array}{l}\text { Low cardiac output } \\
\text { Renal failure }\end{array}$ & $\begin{array}{l}3 \\
1\end{array}$ & Heart failure \\
\hline
\end{tabular}

Follow-UP The initial functional results with fascia lata as a valve substitute were satisfactory (Ionescu et al., 1970a, b; Gonzalez-Lavin and Ross, 1971a; Gonzalez-Lavin, Geens, and Ross, 1970a). In the ensuing months the clinical behaviour of these valves showed a definite variation in valve function related to valve position.

Among the surviving patients, 193 valves were available for follow-up assessment-one to 24 months after surgery, and a critical analysis has been possible on each of the three valve positions. 
Valves in the tricuspid position became regurgitant within three to four months after implantation, and in $60 \%$ replacement of the fascial valve was necessary. The remaining valves are regurgitant to some degree.

Better functional results have been evident in the aortic and mitral positions; however, there is also a different behaviour pattern between valves in these two positions. Valves implanted in the mitral annulus have shown a higher percentage of regurgitation than those in the aortic annulus.

Among 78 mitral fascia lata valves, 59 have been followed for a minimum of one year.

Of these patients, $57.5 \%$ have a competent valve and are asymptomatic. Two of the 59 patients (3.4\%) have died. Among the other patients, 20 $(34 \%)$ have some degree of mitral regurgitation. These 20 patients have been analysed further: $8.5 \%$ have only trivial regurgitation with a minimal puff of dye entering the left atrium during left ventricular angiography. Mild regurgitation was found in $15.3 \%$ and moderate regurgitation in $10 \cdot 2 \%$. Valve failure in patients surviving mitral valve replacement with a mounted fascial valve and followed for at least one year was $5.1 \%$ (Fig. 2).

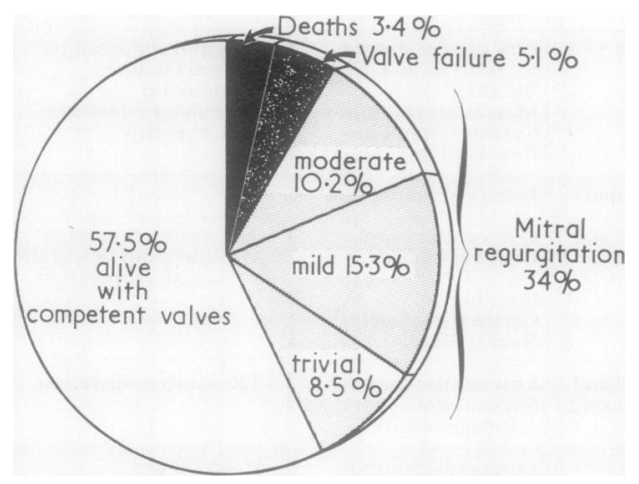

FIG. 2. Results in 59 patients surviving operation for mitral valve replacement at least one year previously.

There has been a common mechanism of failure in all supported fascial valves implanted in the mitral orifice. At reoperation or necropsy regurgitation was found to be due to thickening and retraction of two of the fascial leaflets with fusion of the common commissure due to fibrin deposits. The third cusp remained almost unchanged, perhaps slightly thicker than at the time of insertion. The functioning leaflet in all failed valves occupied the position of the anterior leaflet of the normal mitral valve against the left ventricular outflow tract.

In the total experience with 78 supported fascia lata mitral valve replacements in patients surviving operation, $6.4 \%$ have failed, $34.6 \%$ have some degree of regurgitation, and $59 \%$ have remained competent.

The best functional results have been obtained with valves implanted in the aortic position. In this two-year series 110 valves were available for follow-up, 84 of them for at least one year. Seventy per cent of the 84 patients are alive with a competent valve; four patients $(5 \%)$ have died, and $15(18 \%)$ have aortic regurgitation. Among these 15 patients, 10 have trivial and 5 mild insufficiency, the degree of aortic regurgitation quantitated according to Brandt, Roche, Barratt-Boyes, and Lowe (1969). Valve failure was $7 \%$ in this group (Fig. 3).

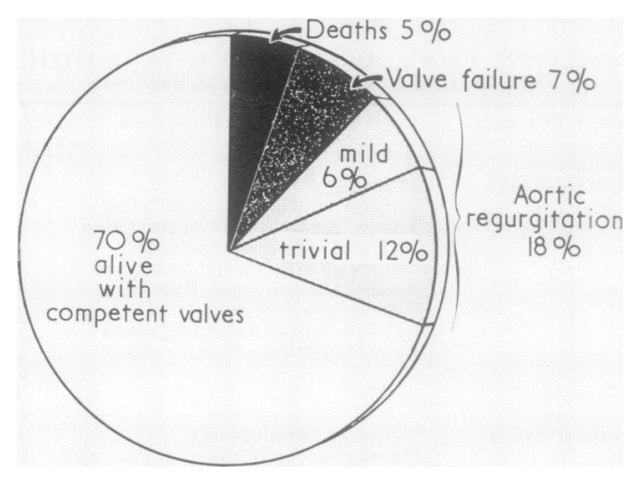

FIG. 3. Results in 84 patients surviving operation for aortic valve replacement at least one year previously.

Failure of the valves implanted in the aortic position has been due to infective destruction of the valve leaflets or retraction of all three leaflets without the preferential retraction observed in the mitral valves. Of the 110 valves in the aortic position, $9 \%$ have failed, one half due to bacterial infection; $16.3 \%$ have some degree of aortic regurgitation and $74.4 \%$ are competent.

The total experience with mounted fascia lata valves is best summarized by graphic comparison (Fig. 4).

\section{DISCUSSION}

Several conclusions can be drawn from the analysis of mounted autologous fascia lata. Hospital and late mortality are comparable to other pro- 


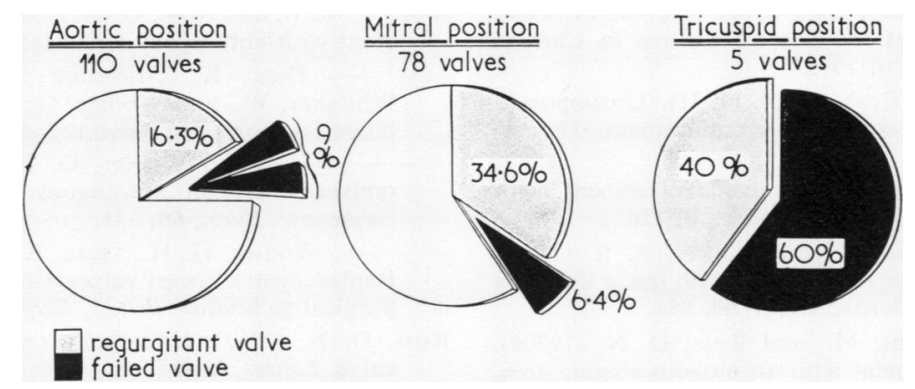

FIG. 4. Graphic comparison of regurgitation and failure in each of the three valve positions in a two-year experience.

cedures for heart valve replacement (GonzalezLavin and Ross, 1970; Gonzalez-Lavin et al., 1970b). Thromboembolism and haemolysis have been uncommon. Postoperative morbidity, however, has shown a higher incidence of complications inherent in the use of fascia lata valves (Table IV). Fifteen per cent of the cases had a wound infection at the fascial donor site; this most likely was responsible for the higher incidence of bacterial endocarditis after operation.

TABLE IV

POSTOPERATIVE MORBIDITY AFTER FASCIA LATA VALVE REPLACEMENT RELATED TO PROCEDURE IN

\begin{tabular}{l|c}
\hline Complication & No. of Patients \\
\hline Leg wound infection & $31(15 \%)$ \\
Bacterial endocarditis & $12(6 \%)$ \\
Peripheral embolism & $2(1 \%)$ \\
Lung infarction & $6(3 \%)$ \\
Haemolysis & $5(2.4 \%)$ \\
Thrombophlebitis & $2(1 \%)$ \\
\hline
\end{tabular}

The exact mechanism responsible for the divergent behaviour related to valve position is unknown. Several factors, however, can be postulated. First, and probably most important, is the accuracy of valve construction: a slight asymmetry of the cusps will interfere with synchronous opening and closing. A difference in tissue thickness of each cusp could also contribute to asynchronism of the leaflets (even in a perfectly constructed valve), compromising the functional mechanism. Minimal elasticity and high tensile strength are properties of fascia lata that do not readily lend to its use as a valve tissue. Autologous living tissue, although it theoretically has the advantage of lasting durability, is capable of stimulating biological reactions and a possible auto-immune mechanism that would enhance the deposition of platelets and fibrin. Organization of this layer may distort the valve leaflet with subsequent thickening and retraction.

The best functional results, thus far, have been in the aortic position. The tri-leaflet fascia lata valves were designed to imitate the shape of a normal aortic valve and consequently offer the best haemodynamics in the aortic position. A full range of motion of the three leaflets is perpetuated by significant opening and closing pressures. In contrast, the haemodynamics of a normal mitral valve are quite different, having a low opening pressure and a preferential flow against the anterior leaflet during systole. This could explain the continued function of the anterior cusp of the fascial valve while the two posterior cusps retract and fuse at their common commissure. Opening and closing pressures are low in the tricuspid area; the range of motion of the fascial valve leaflets is perhaps limited to a point where immobility stimulates the deposition of fibrin with aimost complete retraction of the leaflet as the final outcome.

Concerned with the incidence of valve failure in the tricuspid position and the relatively high incidence of regurgitation in the mitral valves, we have elected to discontinue the clinical use of mounted fresh autologous fascia lata valves, to follow closely the present series of patients, and to reassess the application of this method in the future. In the eight months immediately preceding this analysis there has not been any increase in the degree of regurgitation nor in the appearance of new murmurs.

\section{REFERENCES}

Brandt, P. W. T., Roche, A. H. G., Barratt-Boyes, B. G., and Lowe, J. B. (1969). Radiology of homograft aortic valves. Thorax, 24, 129.

Brownlee, R. T., and Yates, A. K. (1971). A fascia lata mitral valve based on the 'frustum' principle. Thorax, 26, 284. 
Dalichau, H. (1971). Unsupported fascia lata valves: valve design. Paper read at the Second Course in Cardiac Surgery, London, April 19-23.

- Mahjoub, M., and Ross, D. N. (1971). Unsupported fascia lata valve for aortic valve replacement. Thoraxchirurgie. (In press.)

Edwards, W. S. (1969). Aortic valve replacement with autogenous tissue. Ann. thorac. Surg., 8, 126.

- Karp, R. B., Robillard, D., and Kerr, A. R. (1969). Mitral and aortic valve replacement with fascia lata on a frame. J. thorac. cardiovasc. Surg., 58, 854.

Gonzalez-Lavin, L., Geens, M., and Ross, D. N. (1970a). Mitral valve replacement with autologous tissue. Arch. Surg., 101, 760.

- Somerville, J., and Ross, D. N. (1970b). Autologous pulmonary valve replacement of the diseased aortic valve. Circulation, 42, 781.

- and Ross, D. (1970). Homograft aortic valve replacement: A five-year experience at the National Heart Hospital, London. J. thorac. cardiovasc. Surg., 60, 1. (1971a). Autologous fascia lata valves in combined aortic and mitral valve surgery. Ann. thorac. Surg., 12, 236.

(1971b). Late results after aortic valve replacement with homologous valves. Thoraxchirurgie. (In press.)
Ionescu, M. I., and Ross, D. N. (1969). Heart-valve replacement with autologous fascia lata. Lancet, 2, 335.

Deac, R., Grimshaw, V. A., Taylor, S. H., Whitaker, W., and Wooler, G. H. (1970a). Autologous fascia lata for heart valve replacement. Thorax., 25, 46. and Wooler, G. H. (1970b). Heart valve replacement with autologous fascia lata. J. thorac. cardiovasc. Surg., 60, 331.

Wooler, G. H., Deac, R., and Ray, D. (1970c). Replacement of heart valves with autologous fascia lata. Surgical technique. Brit. J. Surg., 57, 437.

Ross, D. N. (1962). Homograft replacement of the aortic valve. Lancet, $2,487$.

_ (1967). Replacement of aortic and mitral valves with a pulmonary autograft. Lancet, 2, 956.

Senning, $\AA$. (1967). Fascia lata replacement of aortic valves. $J$. thorac. cardiovasc. Surg., 54, 465.

- (1969). Results of fascia lata reconstruction of the aortic valve. J. cardiovasc. Surg. (Torino), Special issue devoted to the 17th Congress of the European Society of Cardiovascular-Surgery. London, July 1-3, 1968, p. 28.

Wright, J., Ross, D. N., and Yates, A. (1971). Paper read at the British Cardiac Society, Sheffield, February.

Yates, A. K. (1971). A fascial frustum valve for aortic valve replacement. Thorax, 26, 184. 